\title{
The U.S. Church, the Secular World and the Temptation to "Integrism"
}

\author{
Paul F. Lakeland \\ Fairfield University, pflakeland@fairfield.edu
}

Follow this and additional works at: https://digitalcommons.fairfield.edu/religiousstudies-facultypubs Permission granted by copyright holder: (2011) College Theology Society, publisher of the journal, Horizons.

\section{Peer Reviewed}

\section{Repository Citation}

Lakeland, Paul F., "The U.S. Church, the Secular World and the Temptation to "Integrism"'" (2011). Religious Studies Faculty Publications. 63.

https://digitalcommons.fairfield.edu/religiousstudies-facultypubs/63

\section{Published Citation}

Lakeland, Paul F. "The U.S. Church, the Secular World and the Temptation to 'Integrism'." Horizons 38.1 (Spring 2011): 7-35.

This item has been accepted for inclusion in DigitalCommons@Fairfield by an authorized administrator of DigitalCommons@Fairfield. It is brought to you by DigitalCommons@Fairfield with permission from the rightsholder(s) and is protected by copyright and/or related rights. You are free to use this item in any way that is permitted by the copyright and related rights legislation that applies to your use. For other uses, you need to obtain permission from the rights-holder(s) directly, unless additional rights are indicated by a Creative Commons license in the record and/or on the work itself. For more information, please contact digitalcommons@fairfield.edu. 


\title{
THE U.S. CHURCH, THE SECULAR WORLD AND THE TEMPTATION TO "INTEGRISM"
}

\author{
Paul Lakeland \\ Fairfield University
}

\begin{abstract}
Recent activity among the American Catholic bishops in the social and political arena shows in some cases at least a tendency towards the "heresy" of integrism as defined by Karl Rahner, namely, the inclination to see the ethical teaching of the Church as a blueprint or template for secular society. This article surveys some examples of this tendency. It argues for a vision of the secular world as independent and grace-filled. The constructive proposal towards which this article moves, which is an effort to place the Church's ethical outlook on the secular world in the space between integrism and esotericism, is worked out in dialogue with Rahner, Archbishop Charles Chaput, Archbishop Rowan Williams and Professor James Davison Hunter.
\end{abstract}

The problem is less the death of God than the death of our ideological reassurance of our missionary totalism.

-Michel de Certeau

The challenge to a secularized European culture has been a mark of the papacy of Joseph Ratzinger from its very beginning. Indeed, in the lecture he gave at the monastery of Subiaco on the day before John Paul II died, Cardinal Ratzinger warned against the moralism without rationality that has led to the godless society of contemporary Europe. ${ }^{1}$ The lecture, however, was anything but a condemnation of Enlightenment

${ }^{1}$ On the occasion of receiving the St. Benedict Award (1 April 2005). The full text in English is available at http://www.catholiceducation.org/articles/politics/pg0143.html.

Paul Lakeland is the Aloysius P. Kelley SJ Professor of Catholic Studies and Director of the Center for Catholic Studies at Fairfield University (Fairfield, CT 06824). He recently wrote Church: Living Communion (Liturgical, 2009) and edited Yves Congar: Essential Writings (Orbis, 2010). His current research interests focus around inductive approaches to ecclesiology and he is also at work on a book on Jesuit education provisionally entitled Wrestling with Ignatius.

HORIZONS 38/1 (2011): 7-35 
reason. ${ }^{2}$ In fact, Ratzinger called for entente between a Catholic Christianity that recognizes its root in Logos and a revivified Enlightenment reason that has recovered a sense of moral norms. The Enlightenment, he writes, had its origins in a healthy reaction to a Christian faith that "against its nature and unfortunately, had become tradition and religion of the state." The principal merit of the Enlightenment was that of "having given back to reason its own voice." In the spirit of the true reconciliation between the Church and modernity called for in Gaudium et Spes, said Ratzinger, "it is necessary that both sides engage in self-reflection and be willing to correct themselves."

While one would think that an American culture founded on the constitutional separation of church and state would be well-placed to handle the kind of dialogue that Pope Benedict sees to be necessary in the European context, it is by no means clear that this is the case. American culture remains significantly more religious than its European counterparts and the radical Enlightenment never really touched the young United States in the way that it transformed Europe. The founding fathers were not church-going Christians for the most part, but they were not radical secularists either. One could indeed argue that whereas the European problem has been to keep the secular state from the most extrcme forms of anti-religion, in the United States up to and including the present time, the challenge is the opposite. How, in a nation that espouses the separation of church and state, can its citizens find a way to maintain appropriate limits on the involvement of religion in the political process?

In this context of the challenge to the global Church represented by radically secularized culture, ${ }^{4}$ the specific question to be addressed in the following pages is that of the nature of the Church-world

${ }^{2}$ Cardinal Ratzinger, now Pope Benedict XVI, has his own form of a dialectical reading of the Enlightenment that goes back as far as Hegel and has its classic treatment in the work of the Frankfurt school.

${ }^{3}$ This same distinction between a form of radical secularity that rejects any sense of This same distine that is more amenable to dialogue with normative traditions runs transcendence and one that is more amenable throughout Charles Taylor's A Secular Age (Cambridge, MA: Belknap Press/Harvard University Press, 2007), though his fairly liberal conclusions are not likely to be much support to Pope Benedict's position on issues such as sexual identity or sexual freedom. For an example of the kind of dialogue Cardinal Ratzinger was imagining see his encounter with Jürgen Habermas in their The Dialectics of Secularization: On Reason and Religion, ed. Florian Schuller, trans. Brian McNeil (San Francisco: Ignatius, 2007).

${ }^{4}$ Of course, while Pope Benedict is principally concerned with the shape of Europe, the same struggles are being fought out across the world, including the difficulty of constructively interacting with the many-headed hydra of globalization. relationship revealed in the public face of American Catholicism. ${ }^{5}$ The thesis presented here is that to have, as we currently do in the United States, a Church divided within itself, divided in its attitude and loyalty to its leaders, and whose leaders are themselves often in contentious positions vis-à-vis the state and civil society, is not a healthy situation, nor is it the inevitable result of the need for the Church to "stand up to" secular society or "secular humanism" or "pluralism." "Church" so conceived fails to recognize the true nature of the Church/ world relationship, and perhaps even moves dangerously close to the evils of "integrism" as Karl Rahner defined it, namely, the effort to impose the teachings of the Church as a kind of blueprint or ethical template upon the secular world. ${ }^{6}$ What must be sought, on the contrary, is a different role for the Church vis-à-vis the world, one in which the Church appropriately influences civil society without giving in to the temptation to "integrism"-one, in fact, far closer to the vision of partnership and reciprocal learning that distinguished Vatican II's Gaudium et Spes. ${ }^{7}$

It will be helpful to look briefly at three examples from the American Roman Catholic Church, beginning with the vexed question of when if ever it is appropriate to withhold or threaten to withhold the Eucharist from Catholic politicians considered "soft" on the Church's sternly prolife position on abortion. In the background lies a 2004 memorandum from Cardinal Joseph Ratzinger to Cardinal Theodore McCarrick, then Archbishop of Washington. This Vatican position, which has not changed in the intervening years, stated that the Eucharist should be withheld from those politicians who have a track record of "consistently campaigning and voting for permissive abortion and euthanasia

The choice of focus upon the American context is not motivated by any sense that the U.S. Church's concerns ought to drive the global Church's agenda, but stems rather the U.S. Chure ecclesiology in which reflection on from a the nature of the Church should begin in the concrest in part some length present author's inductive approach to ecclesiology has been worked out at some length 2009), esp. 1-65. All such locally constructed theologies contribute to the larger picture that, at the global level, needs to be a synthesis of those inductive approaches and not, as too often haplevel, needs to be a synthesis of those inint that ignores and consequently does not benefit pens, a deductively-constructed blueprint that ignores and consequently does not benefit from the example of local situations. Is it not possible, for example, that the European situation that so exercises Pope Benedict could benefit from the example churches that have always been minority traditions in their own cultures? ${ }^{6}$ Rahner's discussion of integrism and the opposing tendency, esotericism, is clearest in his article "Church and World" in Sacramentum Mundi: An Encyclopedia of Theology, ed. Karl Rahner et al., 6 vaces, especially in Theologica rism in particular he 10 and 12 (New York: Seabury, 1973, 1974)

${ }_{7}$ Second Vatican Council Pastoral Constitution on the Church in the Modern World Gaudium et Spes) [= GS]; see especially section 44. 
laws," and who are unwilling to change their position "when they have met with their pastor and been instructed by him on the Church's teaching." This statement evidently leaves considerable room for interpretation of the meaning of words like "consistently" and "permissive," and seems on the face of it to imagine a dialogical, persuasive approach to the particular circumstance. It also implies that, once suitably informed, the onus falls on the politician to change his or her aggressively pro-choice advocacy and leaves open the question of the relationship between a Catholic politician's ethical values and her or his sense of responsibility to the law of the land. The appropriate conclusion to draw is that a well-informed Catholic public official will understand that it is not acceptable to advocate a pro-choice position and claim to be a faithful Catholic, but not that he or she cannot, for example, be both "pro-life" and opposed to the recriminalization of abortion.

In June of 2004 the United States Catholic Conference issued a brief document, "Catholics in Political Life," which accurately reflects the Roman perspective on the relationship between public officials and the Church's teaching. The statement proclaims four needs: "to teach clearly and help other Catholic leaders to teach clearly on our unequivocal commitment to the legal protection of human life from the moment of conception until natural death, ... to do more to persuade all people that human life is precious and human dignity must be defended, . . . to act in support of these principles and policies in public life," and "to maintain communication with public officials who make decisions every day that touch issues of human life and dignity." Notable in the document is the combination of unswerving opposition to pro-abortion legislation coupled with a distinct preference for dialogue and communication over confrontation.

Public statements from Catholic bishops on this topic are many and various, but two will suffice to make the point that there is no one position to which they all hew. At one extreme stands the former Archbishop of St. Louis, Raymond Burke, now head of the Apostolic Signatura in the Vatican, who argued that "the person who persists publicly in grave sin is to be denied Holy Communion, and it [Canon Law] doesn't say that the bishop shall decide this. It's an absolute." ${ }^{8} \mathrm{Fh}$

${ }^{8}$ For the full text see http://www.nccbuscc.org/bishops/catholicsinpoliticallife.

shtml. ments are numerous, including those of Bishop Robert Carlson of Sioux Falls, SD, who wrote in August 2004 that "you cannot vote for a politician who is pro-abortion when you have a choice and remain a Catholic in good standing," (http://www.priestsforlife.org/
magisterium/bishops/04-08carlson.htm), and the bishops of Atlanta, Charleston and
"I don't understand the continual debate that goes on about it," he added. "There's not a question that a Catholic who publicly, and after admonition, supports pro-abortion legislation is not to receive Holy Communion and is not to be given Holy Communion." At the other end of the spectrum we find Archbishop Donald Wuerl, Cardinal McCarrick's successor in Washington DC, refusing to deny communion to Speaker of the House Nancy Pelosi and explaining his refusal:

That's the new way now to make your point. We never-the Church just didn't use Communion this way. It wasn't a part of the way we do things, and it wasn't a way we convinced Catholic politicians to appropriate the faith and live it and apply it; the challenge has always been to convince people.

In comments that speak to the deeper issue of the ways in which various bishops interpret authoritative principles, Wuerl added that "incrimination of others has become a hallmark among some groups and individuals in the Catholic Church in our country today," but "the intensity of one's opinion is not the same as the truth. Speaking out of anger does not justify falsehood." The difference between the two bishops is not over the question of abortion but rather over whether sanctions or persuasion have the greater effect. Shall we take the pastoral or the canonical approach? Archbishop Burke opts for canon law, while Archbishop Wuerl questions the appropriateness of using it in this manner. "I stand with the great majority of American bishops and bishops around the world," commented Wuerl, "in saying this canon was never intended to be used this way. . . . I have yet to see where the canonical approach has changed anyone's heart."

A second example is afforded by the furor surrounding the decision of the University of Notre Dame to grant an honorary degree to President Obama. When Notre Dame decided to confer the degree in 2009, numbers of more conservative American Catholics were outraged. Most Catholics were either indifferent to the decision or in favor of it, ${ }^{11}$ but a vocal minority pointed out the discrepancy between this

Charlotte who wrote the same month that "Catholics serving in public life espousing positions contrary to the teaching of the Church on the sanctity and inviolability of human life, especially those running for or elected to public office, are not to be admitted to Holy Communion in any Catholic church within our jurisdictions" (http://www. archatl.com/archbishops/donoghue/20040804.html).

${ }^{10} \mathrm{http} / / /$ www.politicsdaily.com/2009/05/06/archbishop-wuerl-why-i-won-t-denypelosi-communion.

${ }^{11}$ Figures from a Pew Forum poll are available in summary form at http://pewforum. org/Politics-and-Elections/Obama-Catholics-and-the-Notre-Dame-Commencement.aspx. They suggest that as of April 2009 many Catholics (and others) were unaware of the 
decision and the clear statement in the 2004 document quoted above, "Catholics in Public Life," that Catholic institutions should not honor Catholic politicians who were pro-abortion. Opponents pointed out that President Obama is not Catholic, but this did not seem to quiet the opposition. Cardinal Francis George, Archbishop of Chicago and President of the USCC, opined that "It is clear that Notre Dame didn't understand what it means to be Catholic when they issued this invitation." ${ }^{12}$ The bishop of South Bend declined to attend the graduation ceremonies and as of early May in 2009 some sixty or so bishops had spoken publicly against Notre Dame's invitation to the President. Of course, sixty bishops is only a small minority of the entire conference, and their motives may have been mixed. Archbishop Michael Sheehan of Santa Fe spoke forcefully, decrying the combative tactics of many of his fellow bishops. ${ }^{13}$ Throughout the entire period the Vatican remained silent on the matter. On May 4, 2009, John L. Allen wrote in the National Catholic Reporter that "when L'Osservatore Romano published an essay this week suggesting that U.S. President Barack Obama's positions on abortion and other life issues 'have not confirmed fears of radical changes,' it provided the latest confirmation of a glaring difference in tone between the Vatican and the most ardently pro-life circles in the American Catholic Church, including a growing number of American bishops." Allen added that the article did not mention the Notre Dame dispute. ${ }^{14}$

A third and final example has been the staunch opposition of many American bishops to the 2010 Obama health care legislation. Despite their substantial support for many of its motivations, especially the expansion of health care provisions for the needy and uninsured, the bishops opposed the legislation out of fear that some of its provisions would lead to federal funding for abortion. On March 23, 2010, the day the health care legislation was finally passed, Cardinal George issued a statement on behalf of the USCC that stipulated that although the bishops have long sought many of the provisions of the new legislation, and thus applaud them, "nevertheless, for whatever good this law achieves or intends, we as Catholic bishops have opposed its passage because there is compelling evidence that it would expand the role of the federal government in funding and facilitating abortion and

controversy. Of those who were aware a sizable majority supported Notre Dame's decision, though those who attended mass more frequently were more likely to be opposed.

${ }^{12} \mathrm{http}: / /$ www.time.com/time/nation/article/0,8599,1898756,00.html
${ }^{13} \mathrm{http} / / /$ ncronline.org/news/politics/bishop-decries-combative-tactics-minority-usbishops

${ }^{14}$ http://ncronline.org/news/vatican/vaticans-moderate-line-obama-has-deep-roots plans that cover abortion.” The executive order signed by the President the following day enforcing the restrictions on funding of abortions evidently did not satisfy everyone. ${ }^{15}$ In April, Archbishop Raymond Burke criticized the support for the Obama plan offered by vowed women religious as "an absurdity of the most tragic kind" and suggested they should cease identifying themselves as Catholic. ${ }^{16}$ Later the same month Bishop Lawrence Brandt of the diocese of Greensburg, Pennsylvania ordered diocesan newspapers, offices, and parishes not to promote an upcoming recruiting drive by the Sisters of St. Joseph, declaring that they had "publicly repudiated" the U.S. bishops by supporting the Obama health care bill. ${ }^{17}$ No bishop, however, seems to have criticized John McCarthy, retired bishop of Austin, Texas, who gained press attention from supporting the Obama legislation. ${ }^{18}$ Nor to date have the American bishops responded to the June 2010 article in the Vatican-authorized Jesuit journal, Civilta Cattolica, by the distinguished bioethicist Andrea Vicini in which he strongly backed the passage of the Obama legislation. The article praised the law, had harsh words for Republican opposition to it, and indicated that President Obama's executive order was an appropriate response to the reservations of the Catholic bishops. In its most striking passage, Vicini praised the work of the women religious who supported the passage of the plan. ${ }^{19}$

Each of these three examples is interesting for showing significant differences of opinion among members of the U.S. hierarchy and, in each instance, for a much more low-key response to the issue on the part of the Vatican. But their most important lesson may be ecclesiological. It is of course beyond dispute that the Catholic Church, like other religious and secular organizations, has the right to make its positions known and to argue for their incorporation into public policy. But is there a line over which the Church ought not to step? A positive

${ }^{15}$ In fact it seems that there was considerable obtuseness in the response of the bishops to the efforts to persuade them that the Obama plan would not lead to federal funding for abortion, and their opposition has in some measure continued. The extent of the episcopal misunderstandings of the legislation is explored by Timothy Stoltzfus Jose in his article "Episcopal Oversight," Commonweal, June 4, 2010, 8-9.

${ }^{16} \mathrm{http}: / /$ www.lifesitenews.com/ldn/2010/apr/10041201.html html

${ }^{17} \mathrm{http} / / /$ www.huffingtonpost.com/2010/04/20/bishop-nixes-nuns-recruit_n_545159. ${ }^{18} \mathrm{http}: / / \mathrm{la}$

${ }^{19} \mathrm{~A}$ brief discussion of the article can be found at the Catholic News Service site, http://www.catholicnews.com/data/stories/cns/1002303.htm. For the full text of the article, see "La Riforma Sanitaria Negli Stati Uniti, La Civilta Cattolica 3839 (June 2010): cle, see $423-528$. 
response to this question is most often based on the judgment that the Church might endanger its tax free status by inserting itself into political controversies, especially if it seems to be uttering veiled threats about how Catholics should or should not, might or might not vote. There is, however, a more fundamental theological reason for being wary of these practices. It goes to the question of the relationship between the way the grace of God works in and through the Church, and the way in which God's grace is differently present in and through the complexity of the secular world itself. Whenever the Church seems to be proposing its own ethical standpoint as a template for secular society there are reasons to hesitate, not because the Church's positions are wrong, but because the workings of God's grace in the secular world needs to be respected, and the world is not under the jurisdiction of the Church.

The Church is present in the world somewhat differently, depending on whether we focus upon the institutional, hierarchical Church or the living witness of individual Catholics. While, of course, the Church in the first sense is in the world as an historically bound, visible reality, changing its form and its manner of operation across the centuries, interacting with monarchs and democratically-elected leaders, and indeed inevitably colored by the times in which it happens to be living, this historical presence of the Church does not of itself even begin to exhaust the meaning of "the community and sacrament of salvation." The Church as sacrament is only as efficacious as its individual members are faith-filled and loving witnesses to the Gospel. So, thinking about apostolic activity, the Church/world relationship is between the secular world and the baptized Christians who live and work within it. While the institutional Church exercises its prophetic function by teaching at some level of abstraction, the baptized Christian, lay or ordained, lives out her or his prophetic call in baptism by teaching through concrete actions and decisions in the secular world. What this might suggest for the consideration of Catholic public officials and their access to the Eucharist is that while the Church enunciates principles the real teaching is done in the example of holy living offered by the individual Christian, including those public officials struggling openly with the tension between differing responsibilities. Another more traditional way to say this is that the effective ministry of the Church to the world is in direct correlation with the degree to which individual Catholics translate that teaching into apostolic activity. This is partially a matter of education and courage, and partially subject to the realities of ecclesial reception of teaching. In any given instance of failure, the balance between the blind or willful ignorance of the Catholic community and the ineffectualness or even the erroneous character of the teaching is a matter for debate and discernment. $^{20}$

The Church as institution can be so magnificent and so troubling, so sublime and so flawed. It is this Church which can at times make its members proud to be a part of it, and which at other times can make it harder for Christians to believe. It is this Church about which Karl Rahner wrote so eloquently that "if we are honest. . . we must say that to us of today the assent of faith, hope, and charity to this Church as she exists in the concrete does not come easily."21 As Catholics, Rahner continues, we have to live within and identify with "a society made up of individuals and official authorities which all too often appears pitiful, narrow-minded, old-fashioned and out of date." Even after the Council, he says, it may seem to Catholics that the Church "still prefers anxiously to build upon the past which she feels to be true and trusted, rather than upon a creative future which is still unsure."22 And yet the Catholic Christian "nevertheless finds it possible to give a wholehearted and honest assent to this Church as she exists in the concrete."23 Evidently, the assent which we give to the Church is not to these imperfect concrete realities, but to the community of faith behind, and sometimes obscured by, these concrete realities.

The institutional Church is also present differently to the members of the community of faith and to those beyond it, though this distinction does not correspond to that between the Church and the secular world. For Catholic Christians, the Church guards the deposit of faith and ensures the continuing fidelity of the community to the experience of faith in the risen Christ, above all in its liturgical function, including both the sacrament and the preaching of the word. To those beyond the Church, it is perceived most commonly as a concrete historical reality,

${ }^{20}$ Concrete examples abound. When there is only imperfect or even minimal assent of the Catholic community to the teaching of its own Church leaders, the prophetic element of both is cast into doubt. Currently, Church teachings on birth control, the mandatory celibacy of the clergy, same-sex marriage and the process by which pastors and bishops are selected, among many other issues, fall into this category. For a discussion of the relationship between ineffectual teaching and imperfect assent see my Church: Livin Communion, 79-80. For a searching examination of more deep-seated thy Church: Living Communion, 79-80. For a searching examination of more deep-seated theological issue of tradition, "2000). For a thorough discussion of the relationship between magisterial teaching, the "sense of the faithful" and questions of reception, see Ormond Rush, The Eyes of Faith: The Sense of the Faithful and the Church's Reception of Revelation (Washington, DC Catholic University of America Press, 2009).

${ }^{21 " C}$ "Concerning Our Assent to the Church as She Exists in the Concrete," Theological Investigations, vol. 12: Confrontations, trans. David Bourke (New York: Seabury, 1974), 143.

${ }^{22}$ Ibid., 145. 
an actor within the world giving definition to the way of life of Christians and advocating for Christian ethical values. From the perspective of the Christian community itself, however, the relationship of the Church to the world is that of being a sign and sacrament of the world's salvation in Christ. Its presence in the world as an actor among other actors, as an ethical voice among other ethical voices, is secondary to its sacramental significance, just as its significance to Christians themselves as protector and preserver of faith in Christ is more fundamental than its role as guardian of doctrine and morals. But it is also true that while the Church rightly understands its role vis-à-vis the world in this sacramental sense, this does not mean that the world uses the same language to describe it. In other words, its success as a sacrament of salvation will be measured from the "outside" by the way in which it collaborates in the project of building a more humane and compassionate world, even though that may at times mean cooperating in and at times challenging secular projects.

If the role of the Church relative to the world is to be the sign and sacrament of salvation in Christ, then this is very close to theologian James Alison's characterization of the Church as "the regime and discipline of signs":

Signs pointing towards and actually being, God's bringing about of his Kingdom by reconciling all humans together. Signs which are aimed at summoning forth certain shapes of human desire, interpretation, and living together, rather than coercing people into sacred structures. The driving force behind this is the Spirit breathed forth by Jesus in his dying. This alone, this breath of a crucified criminal, unjustly put to death by the breathing together, the conspiratio, of the sacred and the profane authorities of the time, this breath which cannot be tied down, is the holy power which turns apparent dregs of failed humanity into astounding witnesses of the holiness of God. ${ }^{24}$

So, the Church as the regime and discipline of signs, heralding the inbreaking of the reign of God and offering hope for reconciliation between human beings, is the Church that inspires sinners to witness to Christ, in the power of the Spirit, in the world. It is in this witness, oriented to reconciliation and the reign of God, that the enduring saving presence of Christ is to be found, in the lives, words and works of individual Christians from popes to the least noticeable members of the Body of Christ.

${ }^{24}$ "Sacrifice, Law and the Catholic Faith: is secularity really the enemy?", The Tablet Lecture, December 2006, available at http://www.jamesalison.co.uk/pdf/eng36.pdf.
Alison's description of the Church as the "regime and discipline of signs" is offered in support of his claim that the Church is not "a system of goodness." Alison argues that "systems of goodness are terribly dangerous things" because they work "by having rules which determine who is in and who is out." Systems of goodness, explains Alison, are suspect for St. Paul because they "do not counteract people's desires which are run according to the familiar mechanism of gathering people into unanimity against an evil one to be expelled." Thus they are not really voluntary; their adherents are driven by them and become functions of the crystallized group violence which underlies them. The result, quite unintentionally for people who want to be good people, is that they fall willy-nilly into an inability to see "their neighbor as themselves" and consequently perpetuate violence in the name of a religion of peace. ${ }^{25}$ "Crystallized group violence" can be the product of any social system, but is tragically inappropriate to the Church which, at its best, would be "the regime and discipline of signs, made alive by God." As a community of faith in the dying and risen Jesus, "the only sort of goodness we know is that of the penitent," says Alison. Goodness begins in being forgiven, and "that means being daringly patient about forgiving others." We have to learn to treat our neighbor as ourselves, as forgiven sinners, and this and this alone "comes to supersede all other questions of morality which a system of goodness would impose on us." ${ }^{26}$

The saving presence of the Church in the world is to be found in the Church as the community of believers and in the lives and witness of individual believers, not in the Church as Church, which as the regime and discipline of signs can only be effective in and through the ways in which believers enflesh these signs in history, signs "aimed at summoning forth certain shapes of human desire, interpretation, and living together, rather than coercing people into sacred structures." The challenge to the Church is to rid itself of everything which impedes its sign value; the challenge for the baptized is to act in history in faithful witness to the sign which is the Church, both the sign of the Cross and the sign of the Reign of God. The Church is always present as the regime of signs, but the sign becomes sacrament only in the lives of Christians. The temptation of the Church, always needing to be countered by the praxis of believers, is to see itself as a system of goodness and thus to place law and ethics ahead of the nourishment of faith in the gospel.

It will be instructive to place this understanding in juxtaposition to the somewhat different approach to the responsibilities of the Church
${ }^{25}$ Tbid., 9-11.

${ }^{26}$ Ibid., 11 
expressed by Archbishop Charles Chaput in his 2010 address to Baptist ministers in Houston on the fiftieth anniversary of John F. Kennedy's famous effort, also in Houston, to explain how he as a Catholic President would manage his responsibilities to a pluralistic American society. ${ }^{27}$ Chaput was deeply critical of Kennedy's effort, as he describes it, to drive a deep wedge between his Catholic conscience and his duties as President. Chaput recognized the justice of Kennedy's famous remark that if he was forced into a position where his conscience differed from what was expected of him as president, then he would resign the presidency. But despite this, Chaput sees in Kennedy a kind of prototype of the Catholic politician today who, in Chaput's judgment, employs a fundamentally dualistic approach to being a Catholic in public life, whereas-Chaput argued-one cannot simply divorce one's most deeply held religious convictions from one's responsibilities in public service. Kennedy's insistence on the absolute wall of separation between religion and politics was not only a misperception of the constitution and a misunderstanding of the Catholic position, argued Chaput, it also in effect secularized the presidency in order to win it. The result was a more or less complete privatization of religious belief, and that has had very serious consequences for American culture and politics, thinks the archbishop, most of all in the federal law that legalized abortion. "As a nation," he said, "we might profitably ask ourselves whom and what we've really been worshipping in our 40 million "legal" abortions since 1973."28

While it would be sheer folly to disagree with Chaput's principal contention in his 2008 book, Render Unto Caesar, that Catholics are often neither sufficiently well-informed nor courageous enough to represent faithfully the integrity of Catholic life and belief, there are certainly some places where disagreement is possible. This is particularly the case when we ask about strategies for evangelization, and what they might imply for an understanding of the Church/world relationship. To what degree, additionally, might it be the responsibility of the teaching Church that its faithful members are somehow deficient in knowledge or courage? Certainly, if Catholics are ignorant of the teachings of the Church it must at least in part be a failure of the teachers and cannot simply be blamed on blind or willful ignorance. And is it perhaps possible that their putative lack of courage is really a judgment about the

${ }^{27}$ The full text of his speech is available at http://www.catholicculture.org/culture/ library/view.cfm?recnum=9262. In most respects it summarizes and reprises position laid out in much more detail in his book Render Unto Caesar: Serving the pation by living Our Catholic Beliefs in Political Life (New York: Doubleday, 2008).

${ }^{26}$ On Kennedy as "the first Baptist president" see Render Unto Caesar, 133-37. degree to which they fail simply to mirror the positions of the institutional Church? Is a Catholic only courageous when reflecting the teaching of the Church and inevitably cowardly when not quite "getting it"? Are there not possibly some occasions when "dissent" points to inadequacy in the teachings, or at least in their manner of presentation? ${ }^{29}$

Archbishop Chaput's position on the Church-world relationship is very forceful. The danger of this kind of approach is that it can too easily become unintentionally entangled with a negative and disapproving evaluation of the world itself. There is surely something overstated, for example, in Chaput's argument that the "modern" separation of Church and state doctrine "has explicitly anti-Catholic roots in the nineteenth century," that "it grew directly out of bigotry," and that "it began in a bald effort to wall Catholics out of the nation's public life." ${ }^{30}$ Even if there is a measure of truth here, given some of the frankly unproductive attitudes of the nineteenth-century papacy towards church and state issues, it is not surprising that suspicion of Catholics was rife in the young American democracy. His view seems unduly negative. He sometimes fails to recognize that grace is at work in and through the secular world and that this graceful presence of God in the world is not simply a reflection of the grace of God in the Church. Chaput writes:

In our legitimate hopes for a role in American life, Catholics have ignored an unpleasant truth: that there are active, motivated groups in modern American society that bitterly resent the Catholic Church and the Christian Gospel, and would like to silence both. . . Many Catholics since Vatican II have recoiled almost instinctively from traditional images of "the church militant." But like it or not, that is exactly what we are-or should be. We are in a struggle for the souls of our people and our country. We ignore this at our own peril. We also fail as disciples. ${ }^{31}$

What is most disappointing about Chaput's position is that behind these rhetorical excesses there lies a much more substantial approach to the Church/world relationship. The key is to be found in Chaput's awareness that in the end politics is not what the Church is about. Surely there is an institutional side to Church life, and it is undoubtedly correct that Christian involvement in political life, especially lay Christians, is one important way that the Gospel vision of human flourishing is promoted. But the most effective form of evangelization is the

${ }^{29}$ It is a pedagogical truism that poor teachers blame their students while good teachers look for another way to enlighten the classroom darkness.

${ }^{30}$ Render Unto Caesar, 185-86.

${ }^{31}$ Ibid., 187. 
"personal contact and friendship" that reveals that "the Catholic faith is more than a set of principles we agree to, but rather an entirely new way of life. ... People must see that new life being lived. They must see the joy that it brings. They must see the union of the believer with Jesus Christ." ${ }^{32}$ This is an altogether happier ecclesiological orientation than one in which the Church is constantly fixating upon political life.

Rahner is quite helpful in formulating how believing Christians can live one life, as a Christian in the world, not two, as a Christian and a person of the world. ${ }^{33}$ His Church and world essays written at the time of the Council and in the years immediately after it are suffused with a sense of the ambiguity of contemporary life and the impossibility of grasping reality in the way in which it might have been possible in the past. In times gone by, human beings could more or less know what there was to know, and Christians lived in a situation in which, precisely because what there was to know was so accessible, the Church itself was able to comprehend the whole of what there was to know within its theological outlook. In those putatively simpler times, the Christian lived simultaneously within the Christian Church and the Christian world, at least in principle and, in very many places, in practice too. "In former times," writes Rahner in a 1971 essay on the relationship between faith and doctrine, "one's task was to pass from a well integrated, well ordered world of knowledge on to the inconceivable mystery." But today "it is a disordered world of knowledge which cries out for that light which can only be that eternal light which does not yet shine upon any man here below." ${ }^{34}$ All human beings, Christians included, struggle with the character of finite knowledge which is "no longer capable of being reduced to a complete synthesis" and "which is

${ }^{32}$ Tbid., 190 (emphasis in the original).

${ }^{33}$ Rahner discusses this critical idea in a number of places. He first addresses it headon in "The Theological Concept of Concupiscentia," in Theological Investigations, vol. 1 God, Christ, Mary, and Grace, trans. Cornelius Ernst (Baltimore: Helicon Press, 1961) 347-82. A very helpful summary of its meaning and implications can be found in his essay "The Faith of the Christian and the Doctrine of the Church," in Theological Investigations, vol. 14: Ecclesiology, Questions in the Church, The Church in the World trans. David Bourke (New York: Seabury, 1976), 24-46, applied to the Church/world relationship in "Th, 24-46, esp. 34-36. It is more extensively Secularization," in Theological Investigations, "Theological Reflections on the Problem of David Bourke (New York: Seabury, 1977), 318-48). For reas Writings of 1965-1967, trans. from the technical discussion of , 1977), 318-48). For reasons of space we prescind here ence above; it has been ence above; it has been both challenged and estimated in many subsequent discussions. See especially J.P. Kenny, "The Problem of Concupiscence: A Recent Theory of Professor Karl Rahner," The Australian Catholic Record (Sidney) 29 (1952): 290-304 and 30 (1953): 23-32; Mario Ferrugia, "Karl Rahner on Concupiscence: between Aquinas and Hoidegger," Gregorianum 86 (2005): 330-56.

"The Faith of the Christian and the Doctrine of the Church," 35. anti-ideological in character." Secular knowledge proceeds from sources different from those employed in the official teaching of the Church and "is no longer capable of being fully synthesized. . . with the message of revelation to us regarded as an interpretation of this same human life." The modern Catholic, Rahner adds, "has to recognize and unreservedly endure this pluralism in his intellectual life, painful and perilous though it may often seem." 35

In determining the appropriate role of the Church as a historical actor relative to this secular, pluralistic, concupiscent, and non-integrated world, we have to avoid the two tendencies mentioned above, those of integrism and esotericism. The positive relationship of the Church and the secular world cannot be either the effort to impose the teachings of the Church as a kind of blueprint or ethical template upon the secular world, nor can we simply withdraw into a negative, entirely critical posture. The history of the Church-world relationship, argues Rahner, is one of "the Church's growing self-discovery" and of "the increasing emancipation of the world into its own secular nature." So we have to guard against imagining that "all earthly action in the history of the world is nothing but the putting into practice of the principles taught, expounded and applied by the Church." This attitude, says Rahner, is wrong:

It is not possible wholly to derive from the principles of natural law and the gospel the human action which ought to be done here and now, although of course all action must respect those principles. Nor when such action is more than the carrying into effect of those principles and of the official instructions of the Church, does it cease to be morally important from the point of view of God and in relation to him as goal. It still concerns salvation and has to be performed with the absolute earnestness of moral responsibility. It can even be the subject of charismatic inspiration from on high, and, while remaining secular, a factor in the coming of the kingdom of God. ${ }^{36}$

To avoid falling into this trap, thinks Rahner, "the Church herself has a quite new task in relation to this society, a task which might perhaps be characterized as 'prophetic." "37

Rahner is committed to the idea that in a democratic society the Church has the right and responsibility to teach and indeed to have "a program of action," but, he asks, how is it appropriate for the Church to exercise influence beyond stating principles or the praxis of individual

${ }^{35}$ Tbid., 36.

${ }^{36}$ Sacramentum Mundi, 1: 349-50.

${ }^{37}$ "Theological Reflections on the Problem of Secularization," 330. 
Christians? His answer is not crystal-clear. He seems to see the Church's role of "instruction" as prophetic. That is, the teaching on social issues not directly derived from revelation is offered to the world as pastoral/ prophetic, as a kind of solemn and serious advice which, though of course non-binding upon the world, grows out of the Church's concern for the salvation of the world. For this to work it would be necessary for both individual believers and official representatives of the Church to internalize these prophetic impulses. A whole branch of practical theology, which Rahner rather unhappily named "practical ecclesiological cosmology," needs to be developed precisely to reflect upon the relationship between Church and world at any given time.

In moving towards formulating a practical ecclesiological cosmology for our own times we can benefit from the recent writings of Rowan Williams and James Davison Hunter. In a 2006 address given to the Pontifical Academy of Social Sciences, Williams, Anglican Primate and Archbishop of Canterbury, addressed the ambivalence of the Christian church towards the secular world. He identified two forms of secularism which he called "programmatic" and "procedural." The former is the secularism of "negative" liberty in which the role of government is to safeguard freedom of choice and eschew the adoption of any specific moral agenda or particular vision of human emancipation. The latter is a form of secular society in which "religious convictions are granted a public hearing in debate" though not necessarily any privilege. Williams sums up the distinction as one "between the empty public square of a merely instrumental liberalism, which allows maximal private license, and a crowded and argumentative public square which acknowledges the authority of a legal mediator or broker whose job it is to balance and manage real difference." ${ }^{38}$ Obviously enough, neither the Christian Church nor other religious bodies can accept a world in which all transcendental values are comprehensively privatized and declared irrelevant to the formulation of public policies. No calculus of individual and group benefits, thinks Williams, is possible without addressing "the question of how society deals with the actual variety and potential collision of understandings of what is properly human."

While Williams seems largely to agree with Chaput that Christian insights are important to the health of even a secular, pluralistic society, he seems more ready to accept that the Christian voice is simply one important voice in the public square and that all it can and should

${ }^{38}$ This distinction is similar to that employed by Cardinal Ratzinger in his address, "On Europe's Crisis of Culture" (see n. 1 above).

sas"Secularism, Faith and Freedom." The full text can be found at the Archbishop of Canterbury's own website, http://www.archbishopofcanterbury.org/654 want is to be taken seriously, especially in its commitment to the transcendent values of human life. Williams would not share Chaput's conviction that "we are in a struggle for the souls of our people and our country." Procedural secularity guarantees a level playing field for the debate between different voices. Certainly, law may reflect religious or ideological convictions in differing degrees depending on the society we are examining and how persuasive a particular group may have been in promoting one policy or another. In principle, says Williams, no position is "automatically incapable of being enshrined in law." One can in principle win "public arguments about the need to restrict the availability of abortion" and one can "win arguments about legalizing euthanasia." And "it is precisely because such decisions always remain open to argument that they can be lived with." He continues:

[I]n a society where there were rigidly fixed standards of what could rationally or properly be legislated, there would be the danger of such legal decisions becoming effectively irreformable. It would be harder to reopen questions on the basis of shifting moral perceptions. This is indeed a somewhat high-risk position-but if the alternative is a view that absolutizes one and only one sort of public rationality, the risks are higher. ${ }^{40}$

Williams thus rejects both the programmatic secularism that would disqualify religious values from a role in the formation of public policy and any kind of absolutism, ecclesiastical or otherwise, that would enshrine one perspective in secular law (the integrist position). All law in secular society, in other words, is open to revision. It is this, rather than the foolish commitment to negative liberty, that is fundamental to secular liberal democracies.

Here it seems we do encounter a difference of perspective between the public position of many U.S. bishops on the one hand and Williams on the other. The U.S. bishops have made it quite clear that while there are many serious ethical issues which need to be debated in the public arena, opposition to legalized abortion stands out from all the rest. Catholics may in good conscience, they have argued, dissent from official teaching on, say, the death penalty, but opposition to abortion is a fundamental issue because abortion is itself always wrong. Some critics have tried to argue that a Catholic may hold a pro-life position on abortion and yet be opposed to overturning the federal law that allows abortion (this is a common position for Catholic elected officials). Others have had problems understanding why, according to the bishops, the 
death penalty is not an equally serious issue and why same-sex marriage apparently is. The fundamental question to be asked about the bishops' position, however, is not about this or that particular item of concern, but the fact that some ethical issues, in their view, leave no room for negotiation. ${ }^{41}$ It would certainly be difficult to reconcile this with Williams' position and very hard to see how a procedurally secular democracy could entertain a category of values or practices that are a priori not open to discussion. If dialogue is to be possible, it requires a willingness to be persuaded, whereas absolutes evidently foreclose the possibility of serious discussion. ${ }^{42}$ Of course Catholicism, like many other religious traditions, has a set of fundamental religious doctrines which define it and simply cannot be open to change, but these are theological issues with which the public realm is presumably unconcerned. It would be odd, for example, to find the doctrine of the Trinity up for debate between the Church and secular society. Ethical principles (e.g., the fundamental equality in dignity of all human beings or the right to life) are also normative, though unlike theological doctrines they may well need to be explained and justified in the public arena. But dialogue over the reasoning that leads from these principles to particular judgments about their application in society will certainly have to be open to discussion, and presumably in principle open to change, if the word "dialogue" is to mean anything remotely like the same to the Church as it does in the world. So, in a procedurally secular society that guarantees a level playing field and admits positions based on convictions about transcendental values, the Church has to be willing to explain why a pro-life stance admits of no exceptions to opposition to abortion, or why opposition to the death penalty is only almost always right, or why the preservation of family life is somehow threatened by same-sex marriage. Programmatic secularism will exclude the Church's positions from consideration at all; procedural secularism will welcome them, but the welcome will not mean any special treatment, and

${ }^{41}$ The bishops did not themselves refer to these core teachings as "non-negotiables," as is often implied in discussing them. But they are clear that opposition to abortion, euthanasia, embryonic stem-cell research, as well as opposition to same-sex marriage, are among the fundamental ethical issues and the pillars of their political vision for American society. See Forming Consciences for Faithful Citizenship: A Call to Political Responsibility society. See Forming Consciences for Faithul Citizenship: A ship/FCStatement.pdf.

${ }^{42}$ Pope Benedict's views on dialogue are more restrictive. At times he sees interreligious dialogue to be impossible, since the different religions cannot be open to changing their fundamental faith-convictions. However, dialogue with philosophy over the nature and possibility of transcendental principles is both possible and necessary. See, for example, Cardinal Ratzinger's 1996 address on "Relativism: The Central Problem for Faith Today," http://www.ewtn.com/library/curia/ratzrela.htm. nor should it. The confidence we have in the rightness of our ethical stands in a pluralistic world should surely be open to testing before the court of public opinion.

A recent book by James Davison Hunter, the LaBrosse-Levinson Distinguished Professor of Religion, Culture, and Social Thought at the University of Virginia, suggests another step in the project of rethinking church presence in today's world. ${ }^{43}$ Hunter's argument proceeds in three steps. First he reviews the whole range of today's efforts by Christians to change the world, focusing not surprisingly on evangelical movements but by no means excluding Catholic voices. He concluded that all such efforts are wasted because they simply do not work, because they misconstrue the Christian mandate to be co-creators in God's work of making and remaking the world, because they pay too much attention to politics and too little to culture, and because the naiveté of their understandings of how social change occurs has condemned them to their contemporary irrelevance. Second, he calls for a re-thinking of the nature of power and for "post-political witness" in the world. Finally, he develops a case for what he calls a "theology of faithful presence."

The problem with Christian efforts to change the world, Hunter argues, is that their approach is utterly wrong-headed and cannot work. They should not be trying to change the world at all. Hunter sums up the "common view of change" as the belief that culture is changed by individual choices. If enough people make the right choices-because culture is fundamentally about values-culture will change, possibly dramatically and quickly. But culture is not primarily a product of individual choices, he maintains, nor even of artifacts; it is rather a creation of networks, elites, technology and new institutions. The reason, he thinks, that the Christian churches are not a greater force in American culture is because insufficient numbers of their more educated and talented members are prominent in important networks like entertainment, the high-brow press, publishing, the arts and academia. The vitality of the American churches today, he argues, is in the pew rather than in the leadership, but this means that their energies are peripheral to cultural change. Individuals, even great individuals, do not make change unless they are a part of collectives of like-minded individuals.

${ }^{43}$ To Change the World: The Irony, Tragedy, and Possibility of Christianity in the Late Modern World (New York: Oxford University Press, 2010). Hunter, long known for his writings on the "culture wars," is the Director of the Institute for Advanced Studies in Culture at the University of Virginia. His website contains useful short summaries of the argument of the book, chapter by chapter (http://jamesdavisonhunter.com/to-change-the-
world/chapter-abstracts/). 
If we wish to fulfill "the creation mandate" then we have to look to some other means than simply trying to become one political actor among others, trying to motivate the maximum number of individuals to influence the dominant values of the great mass of ordinary people.

Christians fail because they constantly take their understandings of power from those of the dominant strands of the contemporary secular world. Today's world turns to politics and law for solutions to its problems because social consensus is no longer a given. "In short," says Hunter, "the state has become the incarnation of the public weal." "My contention," he continues, "is that in response to a thinning consensus of substantive beliefs and dispositions in the larger culture, there has been a turn toward politics as a foundation and structure for social solidarity." ${ }^{" 44}$ Rejecting the negative liberty theory of the modern state as "wrong because it is impossible," he points out that law and policy imply moral judgments and worldviews. And so, "each and every faction in society seeks the patronage of state power as a means of imposing its particular understanding of the good on the whole of society." ${ }^{35}$ The public becomes conflated with the political, we inflate our expectations of the political process and the will to power comes to dominate our world: "Our times amply demonstrate that it is far easier to force one's will on others through legal and political means or to threaten to do so than it is to persuade them or negotiate rompromise with them." ${ }^{46}$ People of faith and their institutions are no less affected by this shift than others, since they are concerned about public issues and "[a]s a consequence, faith too has become highly politicized." In Hunter's view, the exercise of the will to power, the power of ressentiment, and the factionalism that almost inevitably goes with it mark the attitudes of the Christian Right, the Christian Left and the "neo-Anabaptists." The Right's attitude to the world is one of being "defensive against," that of the left is of "relevance to," while the neo-Anabaptist tradition (he principally discusses the work of Stanley Hauerwas and one or two proponents of Radical Orthodoxy) promotes "purity from" the world. The tragedy is that when Christians and their churches embrace these tactics then they all become "functional Nietzscheans, participating in the very cultural breakdown they so ardently strive to resist." ${ }^{* 8}$

Hunter's ecclesiology imagines a Christian church in which individuals and their communities of faith engage in "the practice of

${ }^{44}$ To Change the World, 103

${ }^{45}$ Ibid., 104.

${ }^{46}$ Ibid., 107

${ }^{47}$ Ibid., 109

${ }^{48}$ Ibid., 175. faithful presence" which "generates relationships and institutions that are fundamentally covenantal in character, the ends of which are the fostering of meaning, purpose, truth, beauty, belonging, and fairnessnot just for Christians but for everyone." It is not difficult for a Catholic to see in Hunter's analysis a close parallel to the models of Church as sacrament, as prophet and as communion, or for a reader of this article to hearken back to the very similar vision of James Alison. It is, in particular, not hard to find echoes of those haunting opening words of Gaudium et Spes, that "the joy and hope, the grief and anguish of the men of our time, especially of those who are poor or afflicted in any way, are the joy and hope, the grief and anguish of the followers of Christ as well." ${ }^{\prime 9}$ But it is to Hunter's credit that his vision suggests how one might correct the Council's tendency to objectify the Church over against the world. The Church shares the lot of modern human beings because the Church is composed of modern human beings, as enmeshed in the concupiscence of the world as they are in the light of Christ.

If Hunter's depiction of faithful presence is one with which Catholics can identify as at least an ideal of Christian life though not something we achieve easily or every day, his analysis of the relationship between the public and the political and its connection to power is something that has a lot to teach today's Church. Political change as a means of making the world more Christian is a dead end. Indeed, changing the world is the wrong question because "it makes the primary subservient to the secondary." The source of the good, God, becomes a tool to achieve the objective of creating "a certain understanding of the good":

When this happens, righteousness can quickly become cruelty and justice can rapidly turn into injustice. Indeed, history is filled with the bloody consequences of this logic and the logic is very much present, even if implicit, on all sides and in all factions of the ongoing culture war. $^{50}$

This sounds similar to Alison's "crystallized group violence" and, indeed, may be what the editor of Horizons was pointing to in a recent editorial where he claimed to detect "a whiff of Donatism" in the current Church. ${ }^{51}$

${ }^{49} \mathrm{GS} 1$, in The Conciliar and Postconciliar Documents, ed. Austin Flannery, OP Northp

${ }^{50}$ To Change the World, 285.

${ }^{51}$ Unsigned editorial, Horizons 37/1 (Spring 2010): 6. 
There are doubtless many reasons why the American Catholic Church is going through a period of declining influence, some of which are probably beyond its control. The power and unpredictability of the markets, the sweeping cultural changes brought about by globalization and the increasingly pluralistic and secularized character of all but the most isolated states are phenomena that form the given background of the mission and ministry of Christians. It is in this particular world that the Church is called to be a sacrament, not in some bygone world that it imagines it can recreate, nor in some re-Christianized utopia. Christ is the lumen gentium, the light of the people, and it is the work of the Church to reflect that light upon the world. We might call to mind here the four characteristics of the "social power" of Jesus as Hunter enumerates them. As Hunter has them, Jesus' power came from submission to the will of God and rejected status and reputation and privilege. It was characterized by "love for fallen humanity" and for creation, and was marked by "the non-coercive way in which he dealt with those outside of the community of faith." 52 How are we doing?

The short answer is that our currently deficient theology of the world impedes our capacity to reflect Jesus' social power. Submission to the will of God requires humility and obedience. In the first place, the Church must bo humble before the grace of God at work in the world independent of its own sacramental status. God's wisdom at work in the world may sometimes act as a corrective to the errors to which the Church as a human institution is prone. If the pagan Cyrus could be the agent of God in restoring the fortunes of Israel, then it is not impossible for the New York Times to be part of God's wake-up call to a complacent Church, even if the newspaper's motives are as nefarious as some of its critics seem to believe. Even a venal attorney bent on lining his own pockets at the Church's expense may be evidence of the will of God at work. Only arrogance leads the Church automatically to dismiss the wisdom of the world, though of course it need not go to the opposite extreme and bow to any and every whim of the times. The God who moves in mysterious ways is at work in creation, something the Council fathers recognized in their insight that the Church not only teaches the world, but also learns from it. ${ }^{53}$ And this should also mean that the Church should enter into dialogue with the secular world in the knowledge that divine wisdom may be present in its insights, wisdom that even the Church may not yet have grasped.

${ }^{52}$ To Change the World, 191.

${ }^{53}$ See GS 44 .
The call to reject status and reputation and privilege returns us to Rahner's prophetic Church and to the Church as a "regime of signs," in Alison's phrase. Being able to respond to this challenge will require a much less defensive attitude than we currently tend to favor. Protecting the reputation of the Church may sometimes be an important consideration but recent events in the Church have shown us that it is most definitely not the highest priority. Becoming defensive happens all too easily when there are internal problems that threaten to become public and damage the Church's public face, as was apparently for so long the case in the failure to respond to many instances of sex abuse, or when secular authority or public culture treats the Church in a way that seems to its leadership to be demeaning. There is a great deal of disrespect for the Church in our culture today. But for all its secularism, materialism and ethical indifference, the world retains a lot of respect for Jesus. All of us in the Church need to meditate on that fact. The majority of American Catholics, lay and ordained, are indistinguishable in lifestyle and values from their unchurched fellow-citizens, and it is not easy to see how we can credibly give witness to counter-cultural values when we have not bought into them.

Love for fallen humanity and for creation brings us to the nub of the issue. It is because we are sinners whom God has forgiven that forgiveness should be in the forefront of our ecclesial posture. Far too many of our current public pronouncements smack of judgmentalism, of that self-righteousness which may indeed be "a whiff of Donatism." "We are the Church and there is the world" is the implication, and its salvation depends upon its conforming to our divinely-inspired answers to its problems. Of course we mostly do not make the mistake of thinking that the Church knows the best tactics for achieving success on this or that issue of public policy, but far too often we give the impression that "we" have the values that "they" do not, and that we need to impress them upon society. Love for fallen humanity begins with the awareness that we are among the fallen and that sometimes we may even have fallen somewhat further than those who do not have the benefit of Christian faith. Whether the Church is right or wrong in its treatment of lesbian and gay Catholics who want their unions to be blessed by the Church, the genuine love that binds them should not simply be dismissed in a subordinate clause of a sentence whose principal point is that their desires are unnatural and their requests impossible to grant. Whether the Church is right or wrong in its claim that all abortions are evil despite the circumstances, prudential judgments of faithful Catholics in agonizing personal circumstances should not be dismissed in a subordinate clause of a sentence whose principal point is that they have excommunicated themselves. Whether the Church is right or 
wrong that Jesus is the one way to salvation, the sincerity of theologians who struggle with the meaning of this claim for those of other faiths cannot be sidelined in a subordinate clause of a sentence whose principal point is to remove them from their professions and even perhaps their livelihood. There is an appropriate way for us to behave as a Christian community, and an inappropriate way; to return to the terminology of James Davison Hunter, the will to power fuelled by ressentiment is not worthy of our high calling. Or, in Archbishop Wuerl's words quoted earlier, "the intensity of one's opinion is not the same as the truth. Speaking out of anger does not justify falsehood." ${ }^{54}$

Fourth and finally, Jesus' social power showed itself in the noncoercive way in which he dealt with those outside the community of faith. The heresy of integrism is apparent, however unintentionally, when the Church seeks to impose a Catholic perspective through the ballot box. Of course, the Catholic position on abortion is that it is an objective evil on grounds that do not depend on the Gospel, and therefore that it is binding on all human beings. But even if this is so, it still does not justify efforts to impose this view through the ballot box. As Archbishop Wuerl and, it would seem, the Vatican believes, the way of persuasion is by far the better course of action, not least because it is the more likely to succeed in the long run. The same can be said for every other ethical position the Church holds. Whether or not we believe it to be an ethical absolute, our success in winning its acceptance will depend on the openness of our Church to genuine dialogue and the transparency of the way in which the Church itself lives by the values it wishes society as a whole to adopt.

Where all this leaves us is with a renewed call to become a community of faith that lives by the gospel, that loves the world in all its concupiscence, and that has the authority to affirm it and to challenge it that comes from the evident effort of the Church to live by the practice of shalom, in faithfulness to Jesus. All Catholics live and work in the world and have the responsibility to be the loving presence of God in all the areas in which they have an influence, but, as Hunter reminds us, the Church as an institution will have more impact if it stops trying to change the world, if it abandons its claims (more common among Evangelicals than Catholics) that America was ever really a Christian nation and that through political action it can restore it to that state. There is something to be said for Hunter's view that the best thing the Church can do for now is "to be silent for a season and learn how to enact their faith in public

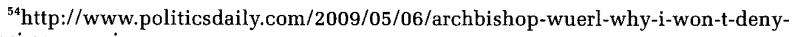
pelosi-communion. through acts of shalom rather than to try again to represent it publicly through law, policy and political mobilization." 55 This is not an argument for social quietism. But it is a call for the Church to be the Church.

Objections to the model of the church-world relationship proposed here might come from more traditional or more liberal perspectives or, indeed, from what Hunter named the neo-Anabaptist school of thought, with which our approach might be confused. To dispense with this last objection first, while the neo-Anabaptist would be attracted to withdrawing the institutional Church from involving itself in the details of the political process, she or he could not accept the love of the world that drives the political dimension of Christian apostolic activity. Nor would the neo-Anabaptists be at all comfortable with the insistence that the baptized Christian is at one and the same time in the church and the world, and open to the workings of divine grace in both spheres. Liberals would applaud the recognition of the secular dimension of the Christian and the turn to the "sinful yet graced" interpretation of secular culture, but would be uncomfortable with the danger that this might lead to a lay-clergy split in which the laity were confined to the secular realm as their sphere of activity, leaving the Church once more as a clerical preserve. And the traditionalists would undoubtedly applaud the call for Christians to bring their values to the workaday world but would strongly resist the implication that they do this ex spiritu and without the need for a strong teaching authority on matters of politics and civil society. These objections are met by the following theological principles. First, the Christian church frees its baptized members to love the world for the sake of the Gospel and to act in the world in the power of the Spirit. Second, the church structures a believing community gathered around the Eucharist, which is itself a politeia given over to the values of the Reign of God, but for the sake of the world of which it is inescapably a part. Third, Christians, who are at home in the secular world as they are at home in the church, find and actualize in the sinful world-as they find and actualize within themselves-the grace of God at work independently of the church.

Our present ecclesial malaise, then, is a direct result of both overestimating and underestimating the power of the Catholic Church. The Church cannot "save the world" but the Church is profoundly important to the health of society. These twin errors could be substantially corrected if we reflected more carefully on the responsibilities entailed in being baptized into the common priesthood of all the faithful. It is this common priesthood, which all-including the ordained-share, which

\footnotetext{
${ }^{55}$ To Change the World, 281.
} 
licenses the missionary activity of Christians in the world. In other words, the church-world relationship is manifest in the activity of the baptized who are at one and the same time secular and religious, at once sinners and graced. We-all the faithful-are the church in the world. The Roman Catholic Church as a visible institution, vis-à-vis the world, is simply one institution among many that make up civil society. The religious meaning of this Church lies in the support it gives to the mission of the baptized, graced and sinful in a graced and sinful world, above all through the liturgy. In the liturgy of word and sacrament it supports the faith of Christians in the saving work of Christ, and everything else it does of value is secondary to this purpose. The Church reflects the light of Christ onto the world when the world sees the faith-filled humanity of countless Christians, grace-filled and sinners like themselves.

We are in danger of radically misconceiving our responsibilities to the work of the Church in the world when we as a Church insert ourselves into political controversy. The temptation to over-reach ourselves and lean towards the integrism against which Rahner warned and which is an ever-present temptation for the Church when it faces what it takes to be an antagonistic world is not wrong solely because it falsely assumes that the world needs a Christian template laid upon it, to replace worldly error with inspired truth. It is also wrong because such a vision can only be implemented if baptized Christians are thought of as so many foot soldiers in a salvation strategy devised by High Command. Baptism does not make some of us foot soldiers and others commissioned officers. It includes us all in a priestly people, called to be prophetic (to teach the world) and to be "kingly" (to serve the world). The Church is there to aid us in this task that baptism has brought upon us, and we would be foolish to ignore the support it has to offer and the instruction that it has to give. But in the last analysis we act in the world through the power of the Holy Spirit who guides us, in the light of our conscience, knowing full well the dangers of our sinfulness and the power of grace.

This position would undoubtedly seem to some to seriously undercut traditional notions of authority in the Catholic Church. While these would certainly accept that the whole people of God is "priestly" in the sense described above, what of the identification of ordained ministry, especially that of the bishop, with "teaching, ruling and sanctifying"? Proclaiming the Church "essentially an unequal society," Pius X famously added that "the one duty of the multitude is to allow themselves to be led and, like a docile flock, to follow the Pastors."

${ }^{56}$ Pope Pius X, Encyclical Vehementer Nos (11 February 1906), §8, http://www.vati can.va/ holy_father/ pius_x/encyclicals/documents/hf_p-x_enc_11021906_vehementernos_en.html it would be rare today to find someone echoing the pope's words exactly, there is much in the kind of pastoral practice we have discussed above that seems not too far from this understanding of the lay-clergy relationship. But the role of Church leadership in matters of civil society not directly connected to revealed truth is one of guidance of the community of faith (Rahner calls it "instruction"), not one of partisan engagement in the political process, nor one of harsh judgments on specific individuals who are adjudged to be at variance from some particular teaching.

That a baptized Christian acts in the world in his or her apostolic, missionary role in virtue of baptism and not by direct commission of the institutional Church is well-attested in the tradition. One of the longer treatments of this complex point is to be found in Yves Congar's efforts to explain the relationship between the ministry of the individual Christian ex spiritu and the formally mandated organizations of Catholic Action. While his purpose is to confirm the benefits of Catholic Action, he insists that it would be wrong "to forget that it is the organization of an already living apostleship, one grounded in the deepest realities of Christian life." 57 "In this context," writes Congar, "every faithful Christian can and ought to adopt the magnificent saying of John Wesley, 'I look upon all the world as my parish."”58 So if the Church is at work in the world in and through the apostolic activity of all the faithful, including the laity, the nature of the individual's relationship to ecclesiastical authority depends upon what is at issue. Individual Christians have no role in formulating basic doctrines or proclaiming fundamental ethical principles, though they can surely try to re-express them in ways their fellow-citizens might grasp. But they have the starring roles in the evangelical drama of simply being the face of Christ in culture and civil society, a task which means that every day, in all that they do, they are willy-nilly interpreting Christian faith in a secular world. This is only possible in the power of the Spirit.

When the energies of Catholic Church leadership in America are not being devoted to damage control because of financial irregularities or, more commonly, the continuing tragedy of sex-abuse, they seem to be disproportionately expended upon campaigning in the political world on a variety of issues and not sufficiently taken up with strengthening the life of faith of the community. We do not have a strong Church

${ }^{57}$ Yves Congar, Lay People in the Church: A Study for a Theology of Laity, trans. Donalt Attwater (Westminster, MD: Newman, 1965), 368. See also Augustine, Tractate on the Gospel of John 51, n.13, and Thomas Aquinas, Summa theologiae III, q. 72.

${ }^{58}$ Lay People in the Church, 366. 
when we have vociferous "church patriotism" 59 working to exercise "crystallized group violence" in the name of the Church as a "system of goodness." We have a strong Church when the life of prayer and sacraments enables a sinful people to engage constructively with the concupiscence of the world of which we are a part. We have a strong Church when we show in our manner of proceeding that our convictions and commitments make for a more compassionate community filled with a concern for human flourishing out of love for God. We do not have a strong Church when are expending energy on laying burdens upon people unnecessarily, or when we are conspicuously preferring the letter of the law to the spirit of the gospel. We have a strong Church when we see it as a community of faith, and a weak Church when we confuse the institutional structures with the life of faith. They are there to enable, they are not "it."

The practical implications of such a view of the Church change the way in which the Church acts in the world. It is of course important for the Church to proclaim doctrine, to teach firmly on ethical principles and to suggest ways in which these doctrines might be defended and these principles might be furthered. But the Church is present in the world as teacher primarily in and through the prophetic activity of the priestly people. Solidarity with victims-compassion for those who suffer and identification with our fellow human beings in the ambiguity of our status as sinners who are yet graced by God-is a reflection of the light of Christ where the enunciation of law is not. We are present in the world as teachers when we embrace the ambiguity of our concupiscent world as it struggles haltingly, but with the grace of God, to move beyond its own sinfulness to embrace the other as a child of God, whether a slave or sweatshop worker, a "mere woman," a gay man or a lesbian. God will find the answers through our apostolic activity in the world; they are not already there in some institutional formulae. The apostle is sent by God, by means of the Church; the true meaning of Church is "the body of those called together in communion and sent by God into the world." Everything else ecclesial is secondary.

While the Church at its more foundational levels, especially in the well-run parish, operates with just such an ecclesiology, the institution does not. The institution has largely lost faith in its own capacity to lead the community of faith, perhaps because its self-understanding is as a system of goodness over against the world, charged somehow to

${ }^{59}$ This phrase from the writings of Simone Weil identifies one of the principal reasons why she, for all her faith, resisted baptism. "What frightens me," she wrote, "is the Church as a social structure" See Waiting for God, trans. Emma Cruafurd (New York: Putnam, 1951), 52-54. persuade the world of the truth of the Church's vision. When this does not happen, indeed when the power of the Church grows weaker, discouragement is not hard to explain. It is almost as if the institution cannot face the prospect that the shape of the Church is changing, perhaps radically, and allows itself to slip into denial. Respect for teaching authority dissipates as credibility wanes, both respect from the wider world that could benefit so much from the wisdom of the Christian tradition, and, sadly, respect within the ranks of faithful Catholics. The role of the Church is to nourish the faith of its members, not to impede their Spirit-empowered apostolicity. And if this sounds a bit much for the average Catholic, or too high-falutin' altogether, then let us finally put it simply in words perhaps more suitable for a homily. The Church is a school of love. The role of the institution vis-à-vis baptized Catholics is to let them loose to love, not to bind them with rules about who or how to love. The future health of our Church depends upon recovering that sense of itself. It is a matter of choosing the social power of Jesus over political power, finding anew a vibrant public presence wholly appropriate to a Church in the world. 